IJLR: International Journal of Law Recontruction

Volume 4, Number 2, September 2020

DOI : http://dx.doi.org/10.26532/ijlr.v4i2.11382

\title{
POLICY ANALYSIS STUDY OF THE TRAFFIC ACCIDENT OF CRIMINAL SYSTEM WHICH MAKE LOSS OF LIFE
}

\author{
Ong Argo Victoria \\ International Islamic University Malaysia \\ argovictoriaupin@gmail.com \\ Ade Riusma Ariyana \\ University of Selamat Sri Indonesia \\ aderiusma@gmail.com
}

\begin{abstract}
There were many cases of traffic accidents area during 2019. These cases were dominated by elements of neglect which resulted in the loss of a person's life. This study aims to determine formal legal considerations in passing decisions on traffic crimes resulting in the loss of a person's life resulting in the death of another person and to analyze the policy on the traffic accident criminal system that results in the loss of a person's life. The research method used is the Normative Juridical Method based on facts, document studies, field surveys and interviews, then analyzed to get a conclusion. The result of this research are the Public Prosecutor uses a single indictment, the indictment prepared by the Public Prosecutor has met the formal and material requirements. And Legal considerations of the Panel of Judges in imposing criminal sanctions against the defendant, the defendant is sentenced to imprisonment for 1 year because he is proven guilty of a criminal act because his negligence caused the death of a person.
\end{abstract}

Keywords: Criminal system; Policy analysis; Traffic Accident.

\section{A. INTRODUCTION}

Indonesia is a rule of law that has a legal rule that is compelling for all people living in Indonesia. As a rule of law, Indonesia is based on law, not only power, so that in Indonesia the legal position is in the highest position (rule of law). ${ }^{1}$ Equality before the law is one of the important principles in modern law, where it is one of the pillars of the Rule of Law doctrine in developing countries like Indonesia, so that this principle is used as a basis for every human being in carrying out law enforcement. ${ }^{2}$.

Law enforcement in modern society is not only defined in a narrow sense but also in a broad sense, such as in Indonesia, law enforcement is

1 Zulkarnain Ridlwan, Negara Hukum Indonesia Kebalikan Nachtwachterstaat, Fiat Justitia Jurnal Ilmu Hukum, Volume 5 No. 2 Mei-Agustus 2012, Page.145

2 Bambang Poernomo, Kapita Selekta Sistem Peradilan Pidana, Universitas Jayabaya, Jakarta, 2016, Page. 76 
associated with the human element and the social environment. ${ }^{3}$ Law enforcement efforts are in line with the principles of the Republic of Indonesia, namely Pancasila ${ }^{4}$. Law enforcement is a prerequisite for a constitutional state, law enforcement always involves humans in it and thus will involve human behavior as well. In essence, criminal law enforcement efforts are also part of law enforcement efforts and are often said to be political or criminal law policies that are part of law enforcement policies (Law Enforcement Police) ${ }^{5}$.

In the traffic regulations in Indonesia it is regulated in statutory regulations, namely Act No. 22 of 2009 concerning Road Traffic and Transportation, where these regulations are made to ensure security, order and welfare in society which need to be determined regarding prohibited and required actions. Meanwhile, any violation of these provisions is punishable by punishment. Often the occurrence of traffic violations, whether intentional or unintentional, may be because the sanctions imposed on the perpetrators of traffic violations are too light, so it is not surprising that there are more and more traffic violations. ${ }^{6}$.

The high number of traffic accidents that claim the most lives caused by traffic accidents needs to be resolved wisely and wisely. Traffic accident crime is a type of crime of negligence, not deliberate. ${ }^{7}$ This is not a crime, but is a criminal offense. In 2017 there were around 9 court decisions related to traffic criminal cases. The verdict handed down in each case is based on considerations of family environment, neighborhood, character, has ever been convicted, whether there is a settlement between the perpetrator and the victim in a family way, all the facts are related to the judge's conviction or all of them are returned to the judge's conscience. The crisis of justice in the administration of justice in Indonesia, especially in the settlement of criminal cases, has caused many reactions. These reactions, there are those that are legally justified or not justified according to law.

The results of research conducted by Subekti, Lushiana Primasari (2014), found that in resolving cases of traffic accidents that resulted in death, serious injuries, minor injuries or metarial losses using the settlement model through legal channels, never using mediation. ${ }^{8}$. Based on the results of research conducted by Muhammad Dani Hamzah on law enforcement in cases

3 Dharma Setiawan Pagaralam, Implikasi Globalisasi dan Penegakan Hukum Progresif di Indonesia, Keadilan Progresif, Volume 02 No. 1, March 2011, Page. 27

4 Achmad Ali, Menguak Tabir Hukum, (Suatu Kajian Filosofis, Sosiologis), Toko Gunung Agung, Jakarta, 2002, Page. 87

5 Barda Nawawi Arief, Bunga Rampai Kebijakan Hukum Pidana, PT. Citra Aditya Abadi, Jakarta, 2014, Page.16-17

6 Ibid.

7 Islah, Pertimbangan Yuridis Penyidik Dalam Menghentikan Penyidikan Perkara Pelanggaran Kecelakaan Lalu Lintas Di Wilayah Hukum Polresta Jambi, Jurnal Ilmiah Universitas Batanghari Jambi, Vol.16 No.3 Tahun 2016, Page. 75

8 Subekti. Lushiana, Model Penyelesaian Perkara kecelakaan Lalu Lintas. Studi Kasus di Kepolisisan Daerah Jawa Tengah, 2014, Page. 239 
of traffic accidents that cause the loss of people's lives, the research results show that law enforcement of traffic accidents that have resulted in the loss of people's lives still has several weaknesses and is for accountability. the penalty has fulfilled the general responsibility. This study is to analyze criminal law enforcement in terms of statutory factors and analysis related to liability in traffic accidentswhich causes the loss of a person's life.

\section{B. RESEARCH METHODS}

This type of research is a qualitative research with a normative juridical approach. Sources of data used in this study are primary data through interviews and secondary data consisting of primary book materials, secondary law and tertiary legal materials which are collected based on the formulated problem topics. ${ }^{9}$ The data collection method used in this research is document study, observation and interview (Interview). The data obtained and collected were analyzed qualitatively.

\section{RESULTS AND DISCUSSION}

Taking into account, Article 310 Paragraph (4) of the Republic of Indonesia Act No. 22 of 2009 concerning Road Traffic and Transportation and Article 310 Paragraph (2) of Law of the Republic of Indonesia No. 22 of 2009 concerning Road Traffic and Transportation ${ }^{10}$ as well as Indonesian Act No. 8 of 1981 concerning Criminal Procedure Law and other relevant laws and regulations, that the judicial process ends with a final decision (verdict) in which there is the imposition of criminal sanctions (punishment), and in that decision the judge states his opinion regarding what has been considered and what the verdict is. And before arriving at this stage, there are steps that must be done beforehand, namely the stage of proof in imposing a crime against the accused. Before entering into an analytical study, researchers have conducted a search for statistical data about the incidence of traffic accidents that resulted in the loss of a person's life in Batang Regency, which shows that the number of victims who died in traffic accidents fluctuates. ${ }^{11}$.

9 Tengku Erwinsyahbana, Ramlan, Penelitian Kualitatif Bidang Ilmu Hukum Dalam Persfektif Filsafat Konstruktivis, Borneo Law Review Journal, Volume 1 No 1, Juni 2017, Page.16-17

10 Act No.22 of 2009 concerning Road Traffic and Transportation

11 Bismar Siregar, Hukum Acara Pidana, Bina Cipta, Jakarta, 1983, Page. 47 
Table 1. Traffic Accidents Cases in Batang Regency 2016-2019

\begin{tabular}{lcccc|c} 
Year & Accident rate & Died & $\begin{array}{l}\text { Serious } \\
\text { injury }\end{array}$ & $\begin{array}{l}\text { Minor } \\
\text { injuries etc. }\end{array}$ & $\begin{array}{l}\text { Estimated } \\
\text { Losses }\end{array}$ \\
\hline $\mathbf{2 0 1 6}$ & 274 & 29 & 30 & 215 & 182 billion \\
\hline $\mathbf{2 0 1 7}$ & 225 & 31 & 31 & 163 & 157 billion \\
\hline $\mathbf{2 0 1 8}$ & 366 & 109 & 8 & 249 & 570 billion \\
\hline $\mathbf{2 0 1 9}$ & 456 & 40 & 21 & 395 & 660 billion
\end{tabular}

From the table above we can conclude that the incidence of traffic accidents in Batang Regency is quite fluctuating, from 2016 to 2017 there was a decrease in the number of accidents, but from 2018 to 2019 each year is increasing, even though the death toll of dance in 2018 has decreased by around $56 \%$. However, the number of minor injuries and losses due to accident cases from 2016 to 2019 is also increasing.

It is included in the analysis that in imposing a criminal case, the judge must be based on two valid evidence which then from the two evidence the judge is convinced that the criminal act accused actually took place and it was the defendant who did it as regulated in article 183 of the Criminal Code. The proof system set out in article 183 of the Criminal Code is called a Negative wettelijke Stelse/ or a system of proof according to the law that is negative in nature.

The proof system in the Criminal Code is said to be reverse proof system because:

1. It is called Wettelijk or according to the law because for proof, the law determines the type and amount of evidence that must be present; ${ }^{13}$

2. It is called negative because the types and numbers of evidence determined by the law have not been able to make the judge have to impose a sentence on a defendant, if the types and quantities of evidence have not been able to give rise to the judge's conviction that such a criminal act. ${ }^{14}$ actually happened and that the defendant was guilty of the criminal act.

12 Batang Regency Government Statistics Data as of January 1, 2020, accessed July 4, 2020, accessed from http: //quraishshihab.com/article/berlalu-lintas/accessed on 7 July 2020

13 Jawade Hafidz, Efektifitas Pelaksanaan Sistem Pembuktian Terbalik Terhadap Perkara Korupsi Dalam Mewujudkan Negara Hukum di Indonesia, Majalah Ilmiah Sultan Agung, Vol 44, No 118, June-August 2009, Page. 49-50

14 Richard Lokas, Barang Bukti Dan Alat Bukti Dalam Kitab Undang-Undang Hukum Acara Pidana, Lex Et Societatis, Volume 3 No. 9, November 2015, Page. 127 
Apart from what the researcher explained above, what the judge needs to do is to be able to convict the perpetrator, indicating that the criminal act he committed fulfills the elements stipulated in the law. From the point of view of the occurrence of prohibited actions, a person will be held responsible for these actions if the action is against the law and there is no justification or negation of the unlawful nature of the crime he committed. And from the point of view of the ability to be responsible, only someone who is able to take responsibility can be held accountable for his actions ${ }^{15}$.

Based on this, criminal liability or mistakes according to criminal law, consists of 3 (three) conditions, namely ${ }^{16}$ :

1. The ability to be responsible or accountable of the maker;

2. The existence of an act against the law, namely the psychological attitude of the offender related to his behavior, namely:

a. Intentional;

b. Careless attitude

3. There is no justification or reason that eliminates criminal liability for the maker

The ability to distinguish between good and bad actions is a function of reason, namely being able to distinguish between what is permissible and what is not. And the ability to determine one's will according to conviction about the merits of the action is a feeling factor, namely being able to adjust his behavior with the realization of what is permissible and what is not. ${ }^{17}$. As a consequence of these two things, of course a person who is unable to determine his will according to conviction of the merits of an act, he has no fault when committing a criminal act, such a person cannot be held responsible. ${ }^{18}$ In the Criminal Code, the issue of the ability to be responsible is contained in Article 44 paragraph 1 of the Criminal Code which reads: "Anyone who commits an act that cannot be held accountable to him because his soul is disabled in growth or disturbed due to disability, is not sentenced". ${ }^{19}$

To determine accountability, a person who commits a criminal act must have an element of an act against the law. ${ }^{20}$ Regarding the nature of being against the law if it is related to the psychological state (soul) of the maker of the criminal act he has committed can be in the form of deliberate (opzet) or

15 Moeljatno, Asas-Asas Hukum Pidana, Rineka Cipta, Jakarta, 2002, Page.49-50

16 Wirjono Prodjodikoro, Tindak-Tindak Pidana Tertentu Di Indoneia, Eresco, Jakarta, 1967,Page.66

17 Ibid.

18 Andri Wijaya Laksana, Arpangi, Juridical Analysis Of Sanctions Trespasser Against Narcotic's Victim Based On Utilitarianism Justice Values, Jurnal Pembaharuan Hukum, Volume VI No.1 Januari-April 2019, Page. 139

19 Ronny Indrawan, Pertanggungjawaban Pidana Eb Sebagai Perantara Dalam Jual Beli Sabu Sabu Berdasarkan Pasal 114 Ayat 1 Undang-Undang Nomor 35 Tahun 2009 Tentang Narkotika Jo. Pasal 44 Ayat (1) Kitab Undang-Undang Hukum Pidana (Kuhp), Calyptra : Jurnal IImiah Mahasiswa Universitas Surabaya, Volume 3 No. 1, Tahun 2014, Page. 10

20 I Gusti Ayu Jatiana Manik Wedanti, A.A. Ketut Sukranatha, Unsur Melawan Hukum Dalam Pasal 362 Kuhp Tentang Tindak Pidana Pencurian, Kertha Semaya, Volume 01 No. 3, Mei 2003,Page. 3 
due to negligence (culpa). ${ }^{21}$ In the theory of deliberate Indonesian criminal law, there are 3 (three) types, namely ${ }^{22}$ :

1. Purposeful intent.

That with purposeful intent, the perpetrator can be held accountable and easily understood by the general public. If intentional like this is in a criminal act, the perpetrator deserves to be subject to criminal law. Because with this purposeful purpose, it means that the perpetrator really wants to achieve a result which is the main reason for this threat of punishment.

2. Intentional conviction of certainty.

This deliberation exists when the doer, by his actions, does not aim to achieve the result which is the basis of the offense, but he knows very well that the result will inevitably follow the action.

3. Intentional convictionally possible.

This deliberate action, which is clearly not accompanied by an image of certainty about the outcome in question, is merely imagining a possible result.

Furthermore, regarding negligence, because it is a form of error that results in a person being held accountable for his actions, as stated in Article 359 of the Criminal Code which states as follows: "Anyone who because of his negligence causes the death of another person is punished with a maximum imprisonment of five years. or confinement for a maximum of one year. "23

Next to determine whether someone can be sentenced to a criminal is whether there is justification or excuse. With the existence of one of the bases for the elimination of a crime in the form of justification, an act loses its unlawful character, so that it becomes again / may be, the making of it cannot be called the perpetrator of a criminal act. However, if there is a basis for erasing in the form of forgiveness, then an action is still against the law, but the maker is forgiven, so he will not be sentenced to punishment. ${ }^{24}$

After paying attention to the verdict. It appears that the judge in verifying the defendant against decision Number: 40 / Pid.B / 2019 / PN Btgit's right. The basis for the judge's consideration in making a decision based on juridical facts revealed before the trial and by law which has been determined as the intended matter includes the indictment of the public prosecutor, the defendant's statement, witness testimony, letters, evidence and elements. the offense charged plus the judge must be sure whether the defendant committed

21 Hariman Satria, Pembuktian Kesalahan Korporasi dalam Tindak Pidana Korupsi, Integritas, Volume 4 Nomor 2, Desember 2018, Page.32

22 Syarifin, Pipin, Hukum Pidana Indonesia, Pustaka Setia, Bandung, 2000, Page.157

23 Berry Jiverson Tumiwa, Kajian Yuridis Malpraktik Kedokteran Yang Mengakibatkan Meninggalnya Pasien Menurut Pasal 359 KUHP, Lex Privatum, Volume 6 No. 7, 2016, Page. 134

24 Muhammad Ridho, The Analysis Of Proofs Justification Argument On The Murder (Studies Of Decisions Number No.4/Pid.Sus.Anak/2016/Pn.Ban), Poenale: Jurnal Bagian Hukum Pidana, Volume 5 No. 4, 2017, Page.1-2 
a criminal act or not as contained in the elements of the criminal act he was accused of. ${ }^{25}$.

Based on the results of a researcher interview with one of the Class II Batang District Court Judges, Mr. Budi Setiawan, SH, who explained that the decision was handed down based on the demands of the public prosecutor and the facts revealed in the trial, these things were taken into consideration for the Panel of Judges to issue a decision on In this case the defendant was charged with the crime of negligence in traffic in Article 310 paragraph (4) of Act No. 22 of 2009 concerning Road Traffic and Transportation ${ }^{26}$.

The Panel of Judges also considers whether there are reasons that can be forgiving or justification. However, in this case there was no basis for eliminating the punishment of the defendant. Therefore, it is stated that the defendant must be accountable for his actions. In this case the verdict handed down by the Panel of Judges was lower than the demands of the Public Prosecutor, this was because there were things that were burdensome and mitigating to the defendant which the Panel of Judges considered in making the verdict. The things that are burdensome and lighten the defendant in this case, namely:

1. Severe circumstances:

- The defendant was not careful in driving his vehicle;

2. Relief conditions:

- The defendant behaved politely in court to admit his actions and promised not to repeat his actions;

- The defendant has never been convicted;

- The defendant has forgiven each other with the victim's family and has given funeral money to the victim's family;

Based on the aforementioned matters and accompanied by the facts revealed in the trial, as well as the criminal charges of the public prosecutor and the criminal threat of the offense concerned, the Panel of Judges conducts deliberation and is of the opinion that the sentence decided is appropriate and in accordance with the sense of justice.

\section{CONCLUSION}

The legal considerations of the Panel of Judges in imposing criminal sanctions against the defendant, the defendant was sentenced to imprisonment for 1 (one) year because he was found guilty of a criminal act because his negligence caused the death of a person. The judge's consideration in applying the criminal provisions against the perpetrator in this case has been appropriate where the judge has considered both juridical considerations, trial facts, witness testimony, existing evidence, judge conviction as well as matters that incriminate and relieve the defendant. In addition to imposing strict

25 Ibid.

26 Researcher's interview with one of the Class II Batang District Court judges Mr. Budi Setiawan, $\mathrm{SH}$ on June 31,2020 
sanctions against the perpetrators of traffic negligence crimes that result in the death of other people, it is also hoped that the Panel of Judges in deciding cases will also pay attention to the non-juridical aspects of the perpetrator's actions and in imposing a crime, the judge is not necessarily based on the letter of the prosecutor's demands. but on two valid pieces of evidence coupled with the judge's conviction. The judge must be more sensitive to see what facts arise at the trial, so that the facts that arise give rise to the judge's conviction that the defendant can or cannot be convicted.

\section{BIBLIOGRAPHY}

\section{Books:}

Achmad Ali, 2002, Menguak Tabir Hukum, (Suatu Kajian Filosofis dan Sosiologis), Toko Gunung Agung, Jakarta;

Bambang Poernomo, 2016, Kapita Selekta Sistem Peradilan Pidana, Universitas Jayabaya, Jakarta;

Barda Nawawi Arief, 2014, Bunga Rampai Kebijakan Hukum Pidana, Citra Aditya Abadi, Jakarta;

Bismar Siregar, 1983, Hukum Acara Pidana, Bina Cipta, Jakarta;

Moeljatno, 2002, Asas-Asas Hukum Pidana, Rineka Cipta, Jakarta;

Subekti Lushiana, 2014, Model Penyelesaian Perkara kecelakaan Lalu Lintas. Studi Kasus di Kepolisisan Daerah Jawa Tengah;

Syarifin, Pipin, 2000 Hukum Pidana Indonesia, Pustaka Setia, Bandung;

Wirjono Prodjodikoro, 1967, Tindak-Tindak Pidana Tertentu di Indoneia, Eresco, Jakarta;

\section{Journals:}

Andri Wijaya Laksana, Arpangi, Juridical Analysis Of Sanctions Trespasser Against Narcotic's Victim Based On Utilitarianism Justice Values, Jurnal Pembaharuan Hukum, Volume VI No.1 Januari-April 2019;

Berry Jiverson Tumiwa, Kajian Yuridis Malpraktik Kedokteran Yang Mengakibatkan Meninggalnya Pasien Menurut Pasal 359 Kuhp, Lex Privatum, Volume 6 No. 7, 2016;

Dharma Setiawan Pagaralam, Implikasi Globalisasi dan Penegakan Hukum Progresif di Indonesia, Keadilan Progresif, Volume 02 No. 1, March 2011;

Hariman Satria, Pembuktian Kesalahan Korporasi dalam Tindak Pidana Korupsi, Integritas, Volume 4 Nomor 2, Desember 2018; 
I Gusti Ayu Jatiana Manik Wedanti, A.A. Ketut Sukranatha, Unsur Melawan Hukum Dalam Pasal 362 Kuhp Tentang Tindak Pidana Pencurian, Kertha Semaya, Volume 01 No. 3, Mei 2003;

Islah, Pertimbangan Yuridis Penyidik Dalam Menghentikan Penyidikan Perkara Pelanggaran Kecelakaan Lalu Lintas Di Wilayah Hukum Polresta Jambi, Jurnal IImiah Universitas Batanghari Jambi, Vol.16 No.3 Tahun 2016;

Jawade Hafidz, Efektifitas Pelaksanaan Sistem Pembuktian Terbalik Terhadap Perkara Korupsi Dalam Mewujudkan Negara Hukum Di Indonesia, Majalah IImiah Sultan Agung, Vol 44, No 118, June- August 2009;

Muhammad Ridho, The Analysis Of Proofs Justification Argument On The Murder (Studies Of Decisions Number No.4/Pid.Sus.Anak/2016/Pn.Ban), Poenale: Jurnal Bagian Hukum Pidana, Volume 5 No. 4, 2017;

Richard Lokas, Barang Bukti Dan Alat Bukti Dalam Kitab Undang-Undang Hukum Acara Pidana, Lex Et Societatis, Volume 3 No. 9, November 2015;

Ronny Indrawan, Pertanggungjawaban Pidana Eb Sebagai Perantara Dalam Jual Beli Sabu Sabu Berdasarkan Pasal 114 Ayat 1 Undang-Undang Nomor 35 Tahun 2009 Tentang Narkotika Jo. Pasal 44 Ayat (1) Kitab Undang-Undang Hukum Pidana (Kuhp), Calyptra: Jurnal IImiah Mahasiswa Universitas Surabaya, Volume 3 No. 1, Tahun 2014;

Tengku Erwinsyahbana, Ramlan, Penelitian Kualitatif Bidang Ilmu Hukum Dalam Persfektif Filsafat Konstruktivis, Borneo Law Review Journal, Volume 1 No 1, Juni 2017;

Zulkarnain Ridlwan, Negara Hukum Indonesia Kebalikan Nachtwachterstaat, Fiat Justitia Jurnal IImu Hukum, Volume 5 No. 2 Mei-Agustus 2012;

\section{Regulations:}

Act No. 1 of 1946 Concerning Criminal Law Regulations;

Act No. 8 of 1981 Concerning Criminal Procedure Law;

RI Act No. 22 of 2009 concerning Road Traffic and Transportation;

\section{Internet:}

Batang Regency Government Statistics Data as of January 1, 2020, accessed July

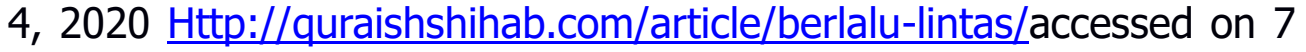
July 2020;

\section{Interview:}

Researcher's interview with one of the Class II Batang District Court judges Mr. Budi Setiawan, SH on June 31, 2020; 